\section{Impact of methodology on the results of economic evaluations of varicella vaccination programs: is it important for decision-making?}

\author{
Impacto da metodologia nos resultados de avaliações \\ econômicas de programas de vacinação da varicela: \\ é importante para o processo de tomada de \\ decisão?
}

\author{
${ }^{1}$ Faculdade de Medicina, \\ Universidade de São Paulo, \\ São Paulo, Brasil. \\ Correspondence \\ P. C. de Soárez \\ Departamento de Medicina \\ Preventiva, Faculdade de \\ Medicina, Universidade \\ de São Paulo. \\ Av. Dr. Arnaldo 455, \\ São Paulo, SP \\ 01246-903, Brasil. \\ pcsoarez@uol.com.br
}

\begin{abstract}
This study aims to review the literature on economic evaluation of childhood varicella vaccination programs and to discuss how heterogeneity in methodological aspects and estimation of parameters can affect the studies' results. After applying the inclusion criteria, 27 studies published from 1980 to 2008 were analyzed in relation to methodological differences. There was great heterogeneity in the perspective adopted, evaluation of indirect costs, type of model used, modeling of the effect on herpes zoster, and estimation of vaccine price and efficacy parameters. The factor with the greatest impact on results was the inclusion of indirect costs, followed by the perspective adopted and vaccine price. The choice of a particular methodological aspect or parameter affected the studies' results and conclusions. It is essential that authors present these choices transparently so that users of economic evaluations understand the implications of such choices and the direction in which the results of the analysis were conducted.
\end{abstract}

Cost-Effectiveness Evaluation; Costs and Cost Analysis; Immunization Programs; Chickenpox
Patrícia Coelho de Soárez 1 Hillegonda Maria Dutilh Novaes 1 Ana Marli Christovan Sartori 1

\section{Introduction}

The exponential growth of health expenditures resulting from the development and incorporation of new technologies puts huge pressure on government budgets and has sparked increasing interest in economic evaluation studies.

Economic evaluation, as an institutionalized practice, proposes to identify, quantify, assess, and compare the costs and consequences of two technologies to be considered. The tool has contributed to greater technical and allocative efficiency in the use of resources in the health system.

Despite the potential usefulness of economic evaluation in the decision-making process, it rarely occurs, even in countries where health technology evaluation agencies provide this type of analysis to administrators. Various characteristics of the political spheres where decisions are made appear to hamper the use of cost-effectiveness analyses. The main characteristics relate to limitations in the capacity to generate, access, and interpret the information contained in economic analyses 1 . The difficulty in understanding such analyses is aggravated by the wide variation in methodologies used.

Using economic evaluations of varicella as an example, the current article points to heterogeneity in the following methodological aspects: perspective, assessment of indirect costs, type of model, modeling of the effect on herpes zoster, 
and estimation of the vaccine's price and efficacy parameters.

Two previous reviews 2,3 of economic evaluations of varicella vaccination programs described the data and study methodologies with the aim of recommending the best vaccination strategies (children, health workers, and other risk groups) to policymakers.

The current study aims to review the literature on economic evaluation of childhood varicella vaccination programs, identify and discuss how the heterogeneity in the methodologies or estimates of parameters can impact the studies' results.

The article begins by reviewing the uncertainties concerning methodological aspects and estimates of parameters and how they can affect the results of analyses.

\section{Perspective adopted in the analysis}

The choice of perspective is the most important point in the analysis, since it determines which costs are included and how they are assessed 4. The healthcare provider or payer's perspective (for example, in Brazil, the Unified National Health System or SUS) includes all the direct medical costs, such as consultations, hospitalizations, medication, and lab tests. Society's perspective includes direct medical costs, plus nonmedical costs, like transportation to the health service and indirect costs or loss of productivity related to the illness, as well as family expenses. Society's perspective is more comprehensive and identifies all the costs and benefits, regardless of who covers the costs or who receives the benefits. There are strong normative arguments that favor adopting society's perspective 5 . Such arguments are related to the principles of social welfare economic theory, according to which when a change in a given policy leads to a series of effects in different individuals and groups, the overall evaluation of the policy's efficiency requires considering all of these implications 6 . Although society's point of view is generally recommended, decision-makers are more interested in the health payer's perspective, because these are the values that directly impact the health systems' budget.

Economic evaluations that adopt society's perspective favor the vaccine's cost-effectiveness.

\section{Indirect costs}

A sick child can generate numerous costs for the parents, including stress, sleep deprivation, family breakdown, and loss of income. Many of these costs, related to pain, suffering, and jeopardized quality of life, classified as intangible costs, are not monetary and are difficult to measure.

Economic analyses in health generally include two categories of costs: direct and indirect. Briefly, direct costs are defined as all the economic consequences directly related to the use of health interventions. Indirect costs are generally related to loss of productivity and family expenditures.

There are two main sources of indirect costs in immunization programs. First, loss of time at work related to the vaccination process itself (vaccine, screening and serological testing, adverse effects). Second, productivity gains due to the reduction in employees' morbidity and mortality, or in the specific case of childhood vaccination programs, the reduction in the number of workdays missed by parents to care for their sick children.

Averted losses of productivity have a major impact on the economic profile of childhood vaccination programs, where most of the savings are generated by reduction in the parents' work absenteeism. Economic evaluations that include indirect costs in their analysis favor incorporation of the vaccine.

\section{Choice of model - static versus dynamic}

The models can be divided into two main categories: static (decision trees and Markov models) and dynamic. The principal difference between these categories is that in static models, the force of infection (the rate at which susceptible individuals become infected) is a fixed parameter, constant over time, and no interactions are observed between individual and population dynamics of the disease. In dynamic models, the force of infection depends on the number of susceptible individuals in the given population 7,8 .

Thus, when the possibility of change exists in the force of infection after immunization (i.e., vaccination blocks transmission of the infection and coverage is expected to be relatively high), dynamic models should be considered 9 .

Dynamic models manage to include herd immunity in their analysis (i.e., indirect protection of susceptible individuals when a large proportion of the population has been vaccinated). When herd immunity is considered in the modeling, vaccination has a greater impact on effectiveness and thus on cost-effectiveness.

\section{Modeling the effect of varicella vaccination on herpes zoster}

The effect of introducing universal childhood varicella vaccination on the incidence of herpes zoster in the population with latent infection 
with varicella zoster virus is still not clear. There are currently two opposing arguments. According to the first, re-exposure to the virus (contact with varicella) stimulates the specific immunity in individuals with latent infection, protecting them against zoster. In this case, universal varicella vaccination, decreasing the circulation of the wild virus in the population, can lead to a significant increase in the number of zoster cases in the short and medium term (as long as there are individuals with latent wild virus infection in the population). Thus, varicella immunization programs may be harmful to public health, since the gain in the reduction of varicella morbidity may be cancelled out by the increase in zoster morbidity. According to the second argument, re-exposure to the wild virus is not a decisive factor in the maintenance of specific immunity and protection against herpes zoster, and thus the incidence of herpes zoster would not be affected by a varicella vaccination program 10 .

The results of models that include the impact on zoster suggest that the odds of vaccination proving cost-effective are very small. Thus, choice of the model can have a profound effect on the estimated attractiveness of varicella vaccination 11. Although data from the modeling suggest that vaccination programs have the potential to modify the epidemiology of herpes zoster, data from the United States where a varicella vaccination program was implemented in 1995 show no evidence that such changes are occurring 12 .

\section{Price and efficacy of the vaccine}

A single dose of the vaccine showed an efficacy of 70 to $90 \%$ in clinical trials $13,14,15,16,17,18$. However, a recent meta-analysis estimated less than $72.5 \%$ effectiveness (95\%CI: 68.5-76.0\%) in the real world ${ }^{19}$. There is growing evidence of decreasing immunity following vaccination (secondary failure of vaccination), which is particularly relevant to public health since it can lead to an increase in susceptibility in older age brackets, in which the risk of severe disease is greater than in childhood 19,20,21. In 2005, in the United States, ten years after the implementation of the national varicella immunization program, the majority of cases occurred in vaccinated individuals 22 . An effectiveness of approximately $85 \%$ for one dose of the vaccine proved insufficient to prevent transmission of the wild-type virus, especially in places like schools with extensive contact. Consequently, since 2006, a second dose of the vaccine (administered to children from 4 to 6 years of age) has been indicated as part of routine immunization in the United States 23,24.

\section{Methods}

\section{Search strategy to identify studies}

A broad and exhaustive search strategy was adopted to identify all the relevant studies. The PubMed, EMBASE, Scirus, Web of Science, and LILACS databases were searched using the key words "varicella" or "chickenpox" and "cost-effectiveness evaluation" or "costs and cost analysis" in English from 1980 to December 2008.

\section{Study selection criteria}

Studies were included in the review when they met the following criteria:

- Study design: full economic evaluation, defined as a comparative analysis of the costs and consequences of two alternative health interventions, including cost-minimization, cost-effectiveness, cost-utility, and cost-benefit analyses.

- Population: children up to 6 years of age.

- Type of intervention: program for universal childhood immunization against varicella.

\section{Results}

\section{Results of literature search}

After reading the abstracts and applying the inclusion criteria, 27 studies were retrieved and analyzed in relation to the previously mentioned methodological differences. Two more articles were added 25,26 from periods studied by previous reviews 2,3, plus four articles 27,28,29,30 published in 2008.

To facilitate the comparability of study results, the monetary values were converted into PPP dollars (Purchasing Power Parity). PPP is the equivalent exchange rate for the price of a basket of goods and services identified in two countries. According to the Brazilian PPP and the exchange rate (from Brazilian Reais or R\$ to US dollars), in 2008 , US $\$ 88$ could purchase the same basket of goods and services in Brazil that US $\$ 100$ could purchase in the United States.

The study results' monetary values were corrected to November 2008 according to each country's inflation rates. Next, all these values were converted into current currencies and transformed into dollars, using the exchange rate presented in the World Bank report, called the ICP (International Comparison Program) available on the World Bank website ${ }^{31}$. Finally, the amounts in US dollars were converted into PPP dollars.

When the study failed to specify the cost year, it was assumed to be two years prior to the study's 
publication. This strategy has been used previously in the literature 3 .

Table 1 shows the abstracts from 27 studies $25,26,27,28,29,30,32,33,34,35,36,37,38,39,40,41,42,43,44,45,46,47$, $48,49,50,51,52$ listed by year of publication (from the oldest to the most recent). The table lists the authors, year of publication, country, type of economic analysis, comparative vaccination strategies, and summary measurements of the results converted into 2008 PPP dollars from the perspectives of the payer and society.

Nearly half $(48 \%)$ of the studies were performed in Europe, including four in Germany $35,42,48,52$, two in France 36,48, three in Spain 27,38,51, three in Italy 29,45,49, one in England and Wales 43, and one in the Slovak Republic 39. Seven studies were performed in North America, including five in the United States 26,28,32,33,34 and two in Canada 40,41. One study was done in New Zealand 37, one in Australia 25, two in Taiwan 44,50 , one in Israel 46, and one in Brazil 30.

According to the authors, 10 studies conducted cost-benefit analyses, 9 cost-effectiveness analyses, 7 cost-benefit plus cost-effectiveness, and only one cost-utility analysis.

The majority of the studies (63\%) adopted both perspectives (payer and society) 28,29,30,34,35, $36,37,40,41,42,43,44,45,46,48,50,51,52$, one study included the patient's perspective 44 , and three did not conduct an analysis from society's perspective 25,26,41.

Considering only the values for vaccination strategies for children up to six years of age, from society's perspective, the benefit-cost ratios (BCR) varied from 1.2327 to 19.33 46. From society's perspective, the BCR represents the reduction of direct and indirect costs from the disease divided by the cost of the vaccination program. A ratio of 19.33:1 means that each dollar invested in the vaccination program saves 19.33 dollars. From the payer's perspective, the incremental cost-effectiveness ratios varied from PPP $\$ 10.7035$ to PPP $\$ 225.6025$ per averted case and from PPP\$3,942 34 to PPP\$33,218 41 per year of life gained.

In Table 2, of the 27 studies that were reviewed, only three $25,26,41$ did not include indirect costs in the economic analysis. The magnitude of indirect costs depended on the number of days of work missed due to varicella and the unit value of workday considered in the analysis. The estimated mean number of workdays missed by parents to care for their sick children varied from 0.6 to 5 days (Table 2). The lowest value (0.6 days) was reported for the first time by Banz et al. ${ }^{42}$, estimated from an epidemiological survey in Germany. Brisson \& Edmunds 43 presented the same figure (0.6 days) based on epidemiological stud- ies in Europe 35,36,53, and Coudeville et al. 48 and Hammerschmidt et al. 52 used the same estimate initially reported by Banz et al. ${ }^{42}$. The highest value (5 days) came from an assumption in the first economic evaluation study on the varicella vaccine 32 , in 1994.

All the studies used the human capital model to assess missed workdays, and in most cases were based on the mean value of the female workday. The lowest value for workday missed by parents (PPP\$12.70) was reported by Coudeville et al. 36 in France, followed by that reported in the Brazilian study (PPP\$13.70) 30 . The values reported by other studies varied from PPP\$45.60 37 to PPP\$326.40 28.

The proportion of indirect costs in the total cost of varicella varied from $42.3 \% 27$ to $98 \% 34$. The highest percentage (98\%), reported by Lieu et al. 34, was explained by the inclusion of future costs related to premature death or prolonged disability related to varicella encephalitis in calculating indirect costs. Indirect costs were also heavily related to domestic policies and regulations. In the specific case of Germany, where a domestic policy requires health plans to reimburse parents for approximately $90 \%$ of the costs of workdays missed to care for sick children ${ }^{52}$, indirect costs were also included in the health payer's perspective 42 .

Table 3 summarizes the various models' characteristics. Of all the studies reviewed, 10 used dynamic models 29,30,36,40,42,43,45,48,51,52, 16 used static models 25,26,27,28,32,33,34,35,38,39,41,44,46,47,49,50, and one study used a pseudodynamic model 37 . The latter model was considered pseudodynamic because it did not incorporate the indirect effects of vaccination on the entire population, but appears to have applied reduced forces of infection to susceptible individuals in the vaccinated cohorts 2 .

Most of the dynamic models 29,36,42,45,51,52 were based on the initial dynamic model developed by Halloran et al. 54, and the others 30,40,43,48 were based on similar approaches. All the dynamic models included the indirect effects of vaccination on non-vaccinated individuals (herd immunity) in the analysis. The study 44 with the Markov model succeeded in simulating the force of infection and attack rate by age bracket in the non-vaccinated group. Another study 46 with a static model reported the partial inclusion of herd immunity, but the article failed to specify its modeling methodology.

Only three studies 26,40,43 included the effect of vaccination on zoster. In the two studies by Brisson \& Edmunds 40,43, the dynamic models assumed that contact with varicella would stimulate immunity against zoster for 20 years, 
Table 1

Economic evaluations of universal childhood vaccination programs against varicella.

\begin{tabular}{|c|c|c|c|c|c|}
\hline $\begin{array}{l}\text { Reference/Year of } \\
\text { publication }\end{array}$ & Country & Type of analysis * & $\begin{array}{l}\text { Vaccination } \\
\text { strategy }\end{array}$ & Payer's perspective & Society's perspective \\
\hline Preblud et al. 32/1985 & USA & Cost-benefit & 15 months & $\mathrm{BCR}=0.30: 1 * \star$ & $\mathrm{BCR}=6.90: 1 \star * \star$ \\
\hline Huse et al. 33/1994 & USA & Cost-benefit & 15 months & NP & $\begin{array}{c}\text { NPV = } 101.2 \text { per vaccinated } \\
\text { individual }\end{array}$ \\
\hline Lieu et al. 34/1994 & USA & $\begin{array}{l}\text { Cost-benefit/Cost- } \\
\text { effectiveness }\end{array}$ & $<6$ years & $\begin{array}{c}\mathrm{BCR}=0.90: 1 \\
3.3 \text { per CA; } 3,942 \text { per } \\
\text { LYS }\end{array}$ & $\mathrm{BCR}=5.40: 1$ \\
\hline \multirow[t]{2}{*}{ Beutels et al. 35/1996 } & Germany & Cost-benefit & 15 months & $\begin{array}{c}\mathrm{BCR}=0.82: 1 \\
\text { 23.1 per } \mathrm{CA} ; 22.145 \\
\text { per LYS }\end{array}$ & $B C R=4.60: 1$ \\
\hline & & Cost-effectiveness & $\begin{array}{l}15 \text { months and } \\
\text { catch-up }\end{array}$ & $\begin{array}{c}\mathrm{BCR}=0.92: 1 \\
10.7 \text { per CA; } 7,759 \text { per } \\
\text { LYS }\end{array}$ & $\mathrm{BCR}=4.72: 1$ \\
\hline Coudeville et al. 36/1999 & France & Cost-benefit & $<6$ years & NP & ANB $=374,898,339$ \\
\hline Scuffham et al. 37/1999 & New Zealand & Cost-effectiveness & 15 months & 31.8 per $\mathrm{CA}$ & 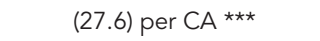 \\
\hline $\begin{array}{l}\text { Díez-Domingo et al. } \\
\text { 38/1999 }\end{array}$ & Spain & Cost-benefit & 15 months & $\mathrm{BCR}=0.54: 1 * \star$ & $\mathrm{BCR}=1.61: 1 * *$ \\
\hline \multirow[t]{2}{*}{ Scuffham et al. 25/1999 } & Australia & Cost-effectiveness & 12 months & 29.2 per CA & NP \\
\hline & & & $\begin{array}{l}12 \text { months and } \\
\text { catch-up }\end{array}$ & 225.6 per CA & NP \\
\hline Hudeckova et al. 39/2000 & $\begin{array}{l}\text { Slovak } \\
\text { Republic }\end{array}$ & $\begin{array}{l}\text { Cost-benefit/Cost- } \\
\text { effectiveness }\end{array}$ & Newborns & $\mathrm{BCR}=0.20: 1$ & $B C R=1.45: 1$ \\
\hline \multirow{6}{*}{$\begin{array}{l}\text { Brisson \& Edmunds } \\
40 / 2002\end{array}$} & Canada & Cost-effectiveness & & Without zoster & \\
\hline & & & 1 year & 46.482 per DYLS & 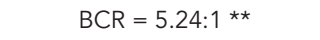 \\
\hline & & & 1 year and catch-up & 53,128 per DYLS & $\mathrm{BCR}=4.90: 1$ ** \\
\hline & & & & With zoster & \\
\hline & & & 1 year & 123,443 per DYLS & NP \\
\hline & & & 1 year and catch-up & 156,662 per DYLS & NP \\
\hline Getsios et al. 41/2002 & Canada & Cost-effectiveness & 12 months & $\begin{array}{l}39.3 \operatorname{per} C A ; 33,218 \\
\text { per } Y L S\end{array}$ & Economical \# \\
\hline \multirow[t]{2}{*}{ Banz et al. 42/2003 } & Germany & Cost-benefit/Cost- & $1-1.5$ years & $\mathrm{BCR}=1.75: 1$ & $\mathrm{BCR}=4.12: 1$ \\
\hline & & & $\begin{array}{l}1-1.5 \text { years and } \\
\text { catch-up }\end{array}$ & $\mathrm{BCR}=1.70: 1$ & $B C R=4.10: 1$ \\
\hline \multirow{2}{*}{$\begin{array}{l}\text { Brisson \& Edmunds } \\
43 / 2003\end{array}$} & England and & Cost-utility & 12-15 months & Dominated \#\# & Dominated \#\# \\
\hline & Wales & & $\begin{array}{l}12-15 \text { months and } \\
\text { catch-up }\end{array}$ & Dominated \#\# & Dominated \#\# \\
\hline Hsu et al. 44/2003 & Taiwan & Cost-benefit & 15 months & $\mathrm{BCR}=0.34: 1 * *$ & $\mathrm{BCR}=2.06: 1 \star * \star$ \\
\hline \multirow[t]{2}{*}{ Coudeville et al. 45/2004 } & Italy & Cost-benefit & 1-2 years & $\mathrm{BCR}=1.20: 1$ & $\mathrm{BCR}=3.50: 1$ \\
\hline & & Cost-effectiveness & $\begin{array}{l}1-2 \text { years and } \\
\text { catch-up }\end{array}$ & NS & NS \\
\hline \multirow{2}{*}{$\begin{array}{l}\text { Ginsberg \& Somekh } \\
46 / 2004\end{array}$} & Israel & Cost-effectiveness & 12 months & $\mathrm{BCR}=1.63: 1$ & $\mathrm{BCR}=19.33: 1$ \\
\hline & & & $\begin{array}{l}12 \text { months and } \\
\text { catch-up }\end{array}$ & $B C R=1.36: 1$ & $\mathrm{BCR}=18.80: 1$ \\
\hline \multirow{2}{*}{$\begin{array}{l}\text { Jean-Jasmin et al. } \\
47 / 2004\end{array}$} & Singapore & Cost-benefit & 15 months & NP & 142.2 per CA \\
\hline & & & $\begin{array}{l}15 \text { months and } \\
\text { catch-up }\end{array}$ & & $B C R=2.25: 1$ \\
\hline \multirow[t]{2}{*}{ Coudeville et al. 48/2005 } & $\begin{array}{l}\text { France and } \\
\text { Germany }\end{array}$ & Cost-effectiveness & 19 months & Cost savings \# & Cost savings \# \\
\hline & & & $\begin{array}{l}19 \text { months and } \\
\text { catch-up }\end{array}$ & Cost savings \# & Cost savings \# \\
\hline Goldman 26/2005 & USA & Cost-benefit & NS & ANC $=82.2$ million & $\mathrm{NP}$ \\
\hline Gialloreti et al. 49/2005 & Italy & Cost-effectiveness & $\begin{array}{l}\text { Childhood } \\
\text { Catch-up }\end{array}$ & NP & $\begin{array}{c}\text { Savings per year }= \\
5,443,245\end{array}$ \\
\hline
\end{tabular}

(continues) 
Table 1 (continued)

\begin{tabular}{|c|c|c|c|c|c|}
\hline $\begin{array}{l}\text { Reference/Year of } \\
\text { publication }\end{array}$ & Country & Type of analysis * & $\begin{array}{l}\text { Vaccination } \\
\text { strategy }\end{array}$ & Payer's perspective & Society's perspective \\
\hline \multirow[t]{2}{*}{ Tseng et al. 50/2005 } & Taiwan & Cost-benefit & $12-18$ months & 80.8 per CA & (136.3) per CA *** \\
\hline & & Cost-effectiveness & & $\mathrm{BCR}=0.54: 1^{\star \star}$ & $\mathrm{BCR}=1.45: 1 * \star$ \\
\hline \multirow[t]{2}{*}{ Lenne et al. 51/2006 } & Spain & Cost-effectiveness & $1-2$ years & 5,197 per LYS & NS \\
\hline & & & $\begin{array}{l}\text { 1-2 years and } \\
\text { catch-up }\end{array}$ & 17,372 per LYS & 11,273 per LYS \\
\hline $\begin{array}{l}\text { Hammerschmidt et al. } \\
52 / 2007\end{array}$ & Germany & Cost-benefit & $\begin{array}{l}\text { 11-23 months and } \\
\text { catch-up }\end{array}$ & $\mathrm{BCR}=1.08: 1 * \star$ & $\mathrm{BCR}=2.56: 1$ ** \\
\hline $\begin{array}{l}\text { Pérez-Rubio et al. } \\
27 / 2008\end{array}$ & Spain & Cost-benefit & 15 months & NP & $B C R=1.23: 1$ \\
\hline \multirow[t]{2}{*}{ Zhou et al. 28/2008 } & USA & Cost-benefit & $\begin{array}{l}1 \text { dose; } 12-15 \\
\text { months }\end{array}$ & $\mathrm{BCR}=1: 1$ & $B C R=4.37: 1$ \\
\hline & & Cost-effectiveness & $\begin{array}{l}2 \text { doses; } 12-15 \\
\text { months }\end{array}$ & $\mathrm{BCR}=0.61: 1$ & $B C R=2.73: 1$ \\
\hline \multirow[t]{2}{*}{ Bonanni et al. 29/2008 } & Italy & Cost-benefit & $1-1.5$ years & $\mathrm{BCR}=0.67: 1 * \star$ & $\mathrm{BCR}=3.47: 1 * \star$ \\
\hline & & & $\begin{array}{l}\text { 1-1.5 years and } \\
\text { catch-up }\end{array}$ & $\mathrm{BCR}=0.64: 1 * \star$ & $\mathrm{BCR}=3.33: 1 \star \star$ \\
\hline \multirow[t]{2}{*}{ Valentim et al. 30/2008 } & Brazil & Cost-effectiveness & 12 months & 28.1 per $C A$ & 31.6 per CA \\
\hline & & & & 12,962 per LYS & 14,573 per LYS \\
\hline
\end{tabular}

Note: all costs in PPP (Purchasing Power Parity) dollars for 2008.

LYS: life year saved; DLYS: discounted life year saved; NPV: net present value; ANB: actualized net benefit; CA: case averted; ANC: annual net costs; NP: not performed; NS: not specified; BCR: benefit-cost ratio.

* As reported by the author;

** This ratio included only costs, not health benefits. From the payer's perspective, it is the reduction in the direct costs of the disease divided by the cost of the vaccination program. From society's perspective, it is the reduction in the direct and indirect costs (loss of productivity) from the disease, divided by the cost of the vaccination program. A ratio of 6.9:1 means that each dollar invested in the vaccination program saves 6.9 dollars;

$\star \star \star$ The incremental cost-effectiveness ratios (ICER) are negative because the strategies generate savings (they are cheaper than the current strategy) and generate more health benefits;

\# The two strategies are cost savings (they are cheaper than the current strategy) and generate more health benefits;

\#\# The two strategies are dominated (they are more expensive than the current strategy) and generate fewer health benefits.

and thus modeled the increase in the number of cases, hospitalizations, and deaths from herpes zoster resulting from vaccination.

In Goldman 26, the static model also assumed that exposure to the wild-type varicella virus would stimulate immunity, protecting against reactivation of herpes zoster, and thus vaccination against varicella would increase the incidence of herpes zoster. The model predicted the number of herpes zoster cases and the associated direct medical costs 30 years after the introduction of vaccination. Goldman calculated that after 50 years, the vaccination program would reach the break-even point, and that net medical savings would accrue from that point onward.

The vaccine prices listed in Table 4 refer only to the dose price and do not include other costs associated with vaccination, such as materials (needles and syringes), overhead, waste, and treatment of adverse events. We chose to present only the price of the vaccine, because the other components are highly subject to the organization of each country's health systems. The vaccine price per dose varied greatly, from PPP $\$ 8.31$ to PPP\$109.21. Ginsberg \& Somekh 46 reported the lowest dose price, explained by the use of a quota for an importer oflarge volumes. The highest price was used in the evaluation by Gialloretti et al. 49 .

Most of the studies used data for the singleantigen vaccine. Only two studies 28,52 used data from the quadrivalent vaccine (MMRV) against measles, mumps, rubella, and varicella. The vast majority of the studies reported efficacy data (percentage of risk reduction in vaccinated individuals as observed in clinical trials). Very few studies 28,52 applied data on effectiveness (percentage of risk reduction in vaccinated individuals, as observed in the real world). The efficacy rates varied from $85 \% 30,50$ to $100 \% 27$. The lowest effectiveness (85\%) reflected the use of results 
Characteristics of indirect costs included in studies from society's perspective.

\begin{tabular}{|c|c|c|c|}
\hline $\begin{array}{l}\text { Reference/Year of } \\
\text { publication }\end{array}$ & $\begin{array}{l}\text { Number of workdays } \\
\text { missed * }\end{array}$ & $\begin{array}{c}\text { Cost per workday } \\
\text { missed }\end{array}$ & $\begin{array}{c}\text { Indirect costs as } \% \text { of } \\
\text { total cost }\end{array}$ \\
\hline Preblud et al. 32/1985 & 5 & 104.7 & 95.0 \\
\hline Huse et al. 33/1994 & 3.7 & 156.8 & 75.7 \\
\hline Lieu et al. 34/1994 & NS & 316.9 & 98.0 \\
\hline Beutels et al. 35/1996 & 2.6 & 224.4 & 95.0 ** \\
\hline Coudeville et al. 36/1999 & 3.4 & 12.7 & NS \\
\hline Scuffham et al. 37/1999 & 3 & 45.6 & $75.9 * \star$ \\
\hline Díez-Domingo et al. 38/1999 & 1.19 & 64.1 & 69.9 \\
\hline Scuffham et al. 25/1999 & $\mathrm{NI}$ & $\mathrm{NI}$ & $\mathrm{NI}$ \\
\hline Hudeckova et al. 39/2000 & NS & NS & $68.9 * *$ \\
\hline Brisson \& Edmunds 40/2002 & $1.7-1.2 * \star \star$ & $81.47-69.98$ & 86.9 \\
\hline Getsios et al. 41/2002 & 3.7 & 36.1 & 61.9 \\
\hline Banz et al. 42/2003 & 0.6 & 217.9 & 72.5 \\
\hline Brisson \& Edmunds 43/2003 & 0.6 & 54.9 & 43.0 ** \\
\hline Hsu et al. 44/2003 & 1.85 & 103.5 & 72.2 \\
\hline Coudeville et al. 45/2004 & 0.7 & 162.7 & 61.1 \\
\hline Ginsberg \& Somekh 46/2004 & 2.5 & $256.2 * \star \star$ & 92.2 \\
\hline Jean-Jasmin et al. 47/2004 & 1.6 & 67.2 & 77.6 \\
\hline Coudeville et al. 48/2005 & $0.7-0.6 \#$ & $202.5-222.8$ \# & $70.5-74.0$ \\
\hline Goldman 26/2005 & $\mathrm{NI}$ & $\mathrm{NI}$ & $\mathrm{NI}$ \\
\hline Gialloreti et al. 49/2005 & 0.6 & 102.2 & 65.0 \\
\hline Tseng et al. 50/2005 & 3.7 & 76.2 & 42.9 \\
\hline Lenne et al. 51/2006 & 0.97 & 100.7 & 71.5 \\
\hline Hammerschmidt et al. 52/2007 & 0.6 & 217.9 & 51.5 \\
\hline Pérez-Rubio et al. 27/2008 & NS & NS & 42.3 \\
\hline Zhou et al. 28/2008 & NS & 326.4 & NS \\
\hline Bonanni et al. 29/2008 & 0.8 & 163.5 & 81.4 \\
\hline Valentim et al. 30/2008 & 0.27 & 13.7 & 47.3 \\
\hline
\end{tabular}

Note: all costs in PPP (Purchasing Power Parity) dollars for 2008.

NS: not specified; NI: not included.

* Mean number of workdays missed by parents or caregivers per episode of varicella;

** Percentage of savings;

$\star \star \star ~ 1.7$ for children 1-4 years of age and 1.2 for children $5-15$ years of age;

\# 0.7, 202.5, and 70.5 in Germany and 0.6, 222.8, and 74 in France.

from studies following introduction of the vaccine in the United States 55,56, while the most optimistic used data from an older clinical trial 13. In studies that used the MMRV vaccine, Hammerschmidt et al. 52 assumed a $95 \%$ efficacy for two doses of vaccine, based on the opinion of experts. Zhou et al. 28 assumed an effectiveness of 93\% for two doses of vaccine, based on the breakthrough rates (primary vaccination failure) among individuals vaccinated with 1 and 2 doses 57 .

As a consequence of the U.S. recommendation of a second dose of vaccine in 2006, three more recent studies analyzed the two-dose vaccine strategy $28,29,52$.
Vaccination coverage rates varied from $10 \% 37$ to $100 \% 26,27,52$. The lowest coverage rate, $10 \%$, represented private sector coverage based on the payer's perspective in the analysis 37 . Goldman 26 assumed $100 \%$ coverage, because vaccination became mandatory in many American states. The highest coverage rates were applied by those that assumed the same coverage obtained for the triple vaccine 27 or used the MMRV vaccine 52 .

Of the 13 studies that reported the rate of decrease in post-vaccination immunity, seven (54\%) used the $3.1 \%$ annual rate from the studies by Brisson et al. 10,58. Four studies used the rate reported by Halloran et al. 54 , where $15 \%$ of the 
Model's characteristics.

\begin{tabular}{|c|c|c|c|}
\hline $\begin{array}{l}\text { Reference/Year of } \\
\text { publication }\end{array}$ & Type of model & $\begin{array}{l}\text { Inclusion of herd } \\
\text { immunity }\end{array}$ & $\begin{array}{c}\text { Inclusion of impact of } \\
\text { vaccination } \\
\text { on zoster }\end{array}$ \\
\hline Preblud et al. 32/1985 & Static & No & No \\
\hline Huse et al. 33/1994 & Static & No & No \\
\hline Lieu et al. 34/1994 & Static & Yes & No \\
\hline Beutels et al. 35/1996 & Static & No & No \\
\hline Coudeville et al. 36/1999 & Dynamic & Yes & No \\
\hline Scuffham et al. 37/1999 & Pseudodynamic & Partially & No \\
\hline Díez-Domingo et al. 38/1999 & Static & No & No \\
\hline Scuffham et al. 25/1999 & Static & No & No \\
\hline Hudeckova et al. 39/2000 & Static & No & No \\
\hline Brisson \& Edmunds 40/2002 & Dynamic & Yes & Yes \\
\hline Getsios et al. 41/2002 & Static & No & No \\
\hline Banz et al. 42/2003 & Dynamic & Yes & No \\
\hline Brisson \& Edmunds 43/2003 & Dynamic & Yes & Yes \\
\hline Hsu et al. 44/2003 & Static & Yes & No \\
\hline Coudeville et al. 45/2004 & Dynamic & Yes & No \\
\hline Ginsberg \& Somekh 46/2004 & Static & Partially & No \\
\hline Jean-Jasmin et al. 47/2004 & Static & No & No \\
\hline Coudeville et al. 48/2005 & Dynamic & Yes & No \\
\hline Goldman 26/2005 & Static & No & Yes \\
\hline Gialloreti et al. 49/2005 & Static & No & No \\
\hline Tseng et al. 50/2005 & Static & No & No \\
\hline Lenne et al. 51/2006 & Dynamic & Yes & No \\
\hline Hammerschmidt et al. 52/2007 & Dynamic & Yes & No \\
\hline Pérez-Rubio et al. 27/2008 & Static & No & No \\
\hline Zhou et al. $28 / 2008$ & Static & No & No \\
\hline Bonanni et al. 29/2008 & Dynamic & Yes & No \\
\hline Valentim et al. 30/2008 & Dynamic & Yes & No \\
\hline
\end{tabular}

successfully vaccinated individuals had lost their immunity by the end of life.

Adverse events were either found at what were considered low rates, ranging from $0.1 \% 32$ to $3.6 \% 37$, or were not considered in the analyses. Five studies $26,27,39,47,52$ did not specify the adverse event rate.

Table 5 shows the most frequent factors that significantly altered the results of the analyses. The factor with the greatest impact on the results was the inclusion of indirect costs, followed by the perspective (society versus payer) and vaccine price.

Some studies reported additional factors, such as vaccine coverage $29,34,35,36,45,51,52$, discount rate $25,28,29,37,40,41,42,43,46,52$, health benefits discount 42 , time horizon ${ }^{43}$, and second dose of vaccine 27,30 .

\section{Discussion}

According to this review, the perspective adopted in the economic evaluations affected the studies' outcome. Where society's perspective was chosen, the vaccination programs were found to be a cost-effective strategy. This confirmed the findings by Thiry et al. 2 , whereby the attractiveness of childhood vaccination was also affected by the perspective adopted for analysis. According to these authors, despite the models' varying data and assumptions, the studies suggested that from society's perspective, universal vaccination at 12 or 15 months of age proved quite attractive since it generated major savings by reducing the number of workdays missed by parents. However, from the payer's point of view, vaccination did not generate savings. Likewise, Rozenbaum et al. 3 stated that from society's perspective, child- 
Vaccine assumptions in economic analyses of varicella.

\begin{tabular}{|c|c|c|c|c|c|c|}
\hline $\begin{array}{l}\text { Reference/Year } \\
\text { de publication }\end{array}$ & Dose price (PPP) & Efficacy (\%) & $\begin{array}{l}\text { Number } \\
\text { of doses }\end{array}$ & $\begin{array}{c}\text { Vaccination } \\
\text { coverage }\end{array}$ & $\begin{array}{l}\text { Annual } \\
\text { waning } \\
\text { rate (\%) }\end{array}$ & $\begin{array}{c}\text { Adverse } \\
\text { effects (\%) }\end{array}$ \\
\hline Preblud et al. 32/1985 & 26.19 & 90.0 & 1 & 90 & NC & 0.1 \\
\hline Huse et al. 33/1994 & 53.31 & 95.0 & 1 & NS & NS & 1.0 \\
\hline Lieu et al. 34/1994 & 55.20 & 90.0 & 1 & 97 & 15.0 * & 2.0 \\
\hline Beutels et al. 35/1996 & 84.16 & 90.0 & 1 & 70 & 15.0 * & NC \\
\hline Coudeville et al. 36/1999 & 20.53 & 90.0 & 1 & 80 & 15.0 * & 1.0 \\
\hline Scuffham et al. 37/1999 & 51.38 & 95.0 & 1 & 10. 80 ** & NC & 3.6 \\
\hline Díez-Domingo et al. 38/1999 & 40.10 & 90.0 & 1 & 95 & NC & 2.0 \\
\hline Scuffham et al. 25/1999 & 52.49 & 95.0 & 1 & 80 & NC & 1.8 \\
\hline Hudeckova et al. 39/2000 & 29.12 & 90.0 & 1 & NS & NC & NS \\
\hline Brisson \& Edmunds 40/2002 & $62.67 \star \star \star *$ & 90.0 & 1 & 90 & 3.1 & NC \\
\hline Getsios et al. 41/2002 & 61.98 & 90.0 & 1 & 85 & 15.0 * & 0.3 \\
\hline Banz et al. 42/2003 & 73.86 & 86.0 & 1 & 85 & 0.5 & 2.0 \\
\hline Brisson \& Edmunds 43/2003 & 54.92 & 90.0 & 1 & 90 & 3.1 & NC \\
\hline Hsu et al. 44/2003 & 82.11 & 95.0 & 1 & 95 & NS & 2.0 \\
\hline Coudeville et al. 45/2004 & 50.64 & 97.0 & 1 & 90 & 3.1 & 1.5 \\
\hline Ginsberg \& Somekh 46/2004 & 8.31 & 87.6 & 1 & 94 & 3.1 & 2.0 \\
\hline Jean-Jasmin et al. 47/2004 & 58.78 & 90.0 & 1 & NS & NC & NS \\
\hline Coudeville et al. 48/2005 & $61.44-67.52 \#$ & 97.0 & 1 & 90 & 3.1 & 1.5 \\
\hline Goldman 26/2005 & NS & 100.0 & 1 & 100 & NS & NS \\
\hline Gialloreti et al. 49/2005 & 109.21 & NS & 1 & 90 & $\mathrm{NC}$ & $\mathrm{NC}$ \\
\hline Tseng et al. 50/2005 & 43.71 & 85.0 & 1 & 80 & NC & 2.0 \\
\hline Lenne et al. 51/2006 & 40.40 & 97.0 & 1 & 97 & 3.1 & 1.0 \\
\hline Hammerschmidt et al. 52/2007 & 55.53 & 95.0 & 2 & $90-100 \# \#$ & 0.5 & NS \\
\hline Pérez-Rubio et al. 27/2008 & 39.49 & 100.0 \#\# & 1 & 100 & NS & NS \\
\hline Zhou et al. 28/2008 & $60.31-70.82 \S$ & 93.0 & 2 & 95 & NC & $1.0-0.5 \S \S$ \\
\hline Bonanni et al. 29/2008 & 45.99 & 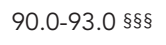 & 2 & 85 & 3.0 & 2.0 \\
\hline Valentim et al. 30/2008 & 37.96 & 85.0 & 1 & 80 & NC & $\mathrm{NC}$ \\
\hline
\end{tabular}

NC: not considered; NS: not specified; PPP: purchasing power parity.

* $15 \%$ of successfully vaccinated individuals will have their immunity exhausted by the end of their lives;

** $10 \%$ from the consumer's perspective and $80 \%$ from society's perspective;

$\star \star \star$ In addition to the price of the vaccine dose, administration, storage, reserve vaccines, transportation, materials, and other costs;

\# 61.44 in France and 67.52 in Germany;

\#\# 90\% after first dose and 100\% after second dose;

\#\#\# In the first year of life;

$\S 60.31$ for the public sector and 70.82 for the private sector:

$\S \S 1 \%$ after first dose and $0.5 \%$ after second dose;

$\S \S \S 90 \%$ after first dose and $93 \%$ after second dose.

hood vaccination programs have always saved costs, with the exception of those that took the potential impact on herpes zoster into account.

Despite the important debate in the literature on the most appropriate method (human capital versus friction cost) for assessing social losses resulting from the disease 59 , all the studies used the human capital method to assess the workday value. The variability in the value of the workday lost by parents, from PPP\$12.70 to PPP\$326.40 28, highlights the wide variation in wage scales between the different countries studied.

Although PPP supposedly corrects these differences in price levels, it fails to completely cancel out these disparities. Thus, in the more economically developed countries, where wages are higher, the analyses are more favorable to introduction of the vaccine, because the amount 
Table 5

Impact of methodology and parameters on the results of economic analyses for varicella.

\begin{tabular}{|c|c|c|c|c|c|c|}
\hline $\begin{array}{l}\text { Reference/Year } \\
\text { de publication }\end{array}$ & Perspective & $\begin{array}{l}\text { Indirect } \\
\text { costs }\end{array}$ & Model & $\begin{array}{l}\text { Herpes } \\
\text { zoster }\end{array}$ & $\begin{array}{l}\text { Vaccine } \\
\text { price }\end{array}$ & $\begin{array}{l}\text { Vaccine } \\
\text { efficacy }\end{array}$ \\
\hline Preblud et al. 32/1985 & Yes & Yes & & & Yes & \\
\hline Huse et al. 33/1994 & & Yes & & & & \\
\hline Lieu et al. 34/1994 & Yes & Yes & & & Yes & \\
\hline Beutels et al. 35/1996 & Yes & Yes & & & & Yes \\
\hline Coudeville et al. 36/1999 & Yes & Yes & Yes & & & \\
\hline Scuffham et al. 37/1999 & Yes & Yes & & & Yes & Yes \\
\hline Díez-Domingo et al. 38/1999 & Yes & Yes & & & & \\
\hline Scuffham et al. 25/1999 & & & & & Yes & \\
\hline Hudeckova et al. 39/2000 & & Yes & & & & \\
\hline Brisson \& Edmunds 40/2002 & Yes & Yes & Yes & Yes & Yes & Yes \\
\hline Getsios et al. 41/2002 & & & & & Yes & \\
\hline Banz et al. 42/2003 & & Yes & Yes & & Yes & \\
\hline Brisson \& Edmunds 43/2003 & & & Yes & Yes & & Yes \\
\hline Hsu et al. 44/2003 & Yes & Yes & & & Yes & \\
\hline Coudeville et al. 45/2004 & & & Yes & & Yes & \\
\hline Ginsberg \& Somekh 46/2004 & & Yes & & & Yes & \\
\hline Jean-Jasmin et al. 47/2004 & & Yes & & & & \\
\hline Coudeville et al. 48/2005 & \multicolumn{6}{|c|}{ Alteration of all the parameters did not modify the result of the analysis } \\
\hline Goldman 26/2005 & \multicolumn{6}{|c|}{ Yes } \\
\hline Gialloreti et al. 49/2005 & \multicolumn{6}{|c|}{ Did not analyze sensitivity of the parameters. } \\
\hline Tseng et al. 50/2005 & Yes & Yes & & & & \\
\hline Lenne et al. 51/2006 & Yes & Yes & Yes & & & \\
\hline Hammerschmidt et al. 52/2007 & & Yes & Yes & & & \\
\hline Pérez-Rubio et al. 27/2008 & Yes & Yes & & & & \\
\hline Zhou et al. $28 / 2008$ & Yes & & & & Yes & \\
\hline Bonanni et al. 29/2008 & Yes & Yes & Yes & & Yes & \\
\hline Valentim et al. 30/2008 & & & Yes & & Yes & \\
\hline
\end{tabular}

of indirect costs saved is higher, thus underscoring one of the main critiques of the human capital method, which assesses productivity based on income. The vaccine proved more attractive where wages are higher, because according to the human capital method, persons are worth what they produce for society.

To determine the impact of indirect costs on total cost of varicella, indirect costs as a proportion of the total cost of the disease were presented. The results should be interpreted with caution, because the definition of indirect costs differed somewhat between studies and because the measurement and assessment of indirect costs varied greatly. While some studies only included losses of productivity in the form of workdays lost by parents to care for their children, others also included the cost of death or prolonged disability resulting from the disease.
Estimation of the number of workdays lost also varied between studies. While some authors 48,52 repeated the value ( 0.6 days) initially reported by Banz et al. 42 or presented the same value 43 as in epidemiological studies conducted in Europe 35,36,53, others assumed a higher figure (5 days). It was not surprising that the highest percentage of indirect costs in the total cost of varicella (98\%) 34 was associated with the second highest cost of a workday (PPP\$316.90). Overestimation of these data biases the results of the analysis in favor of the vaccine.

The definition of indirect cost determines which values will be included in its calculation. Together with the value of the workday, they can have a huge impact on the results of the analysis. All evaluations that included indirect costs in their calculation favored the vaccination program, and the higher the value attributed to in- 
direct costs, the more favorable the incremental cost-effectiveness ratio (ICER).

All the economic evaluations that employed dynamic models included herd immunity in the analysis and favored the vaccination program.

Due to the complexity of developing dynamic models, various authors tend to use the same model in different contexts. Several authors have used the dynamic model designed by Halloran et al. 54 to evaluate the cost-effectiveness of their vaccination programs.

This model indicated that vaccination of children at 12 months reduced both varicella incidence and hospitalization in the United States. However, the study investigated a small number of vaccination policies and coverage rates, assumed optimistic vaccine efficacy rates, adopted an age structure that did not reflect varicella epidemiology precisely, and did not conduct a sensitivity analysis in the "Who Acquires Infection from Whom" matrix (WAIFW) 36 .

In addition, this model focused mainly on the change in varicella incidence and morbidity due to changes in the age at infection, and failed to explore the possible effects of vaccination on zoster epidemiology.

These issues emphasize the importance of clarity in the models' methodology and assumptions, as well as a justification for the choices and discussion of the possibility of using the same model in different contexts. Taking the WAIFW as an example, can a single matrix represent the age structure and contact pattern in different countries?

The three studies $26,40,43$ that included the effect of vaccination on zoster assumed that contact with varicella would stimulate immunity against zoster, and thus modeled the increase in incidence, mortality, and use of resources related to zoster treatment.

The model 10 adopted in the two studies by Brisson \& Edmunds 40,43 predicted an increase in post-vaccination zoster incidence for a period of 60 years 10,40,43,60. However, they recognized the lack of knowledge on the mechanisms that trigger zoster and the model's structure, and the estimated parameters are speculative and probably oversimplified.

Given the complexity and unpredictable interactions between childhood varicella vaccination and herpes zoster incidence, the safest options for vaccination programs would be: (1) vaccination targeting adolescents, adults, and other high-risk susceptible groups. In this case, only a limited proportion of the population is vaccinated, and there is no impact on either virus transmission in the community or herpes zoster incidence; (2) vaccination against varicella in childhood and vaccination against zoster for individuals at increased risk of reactivation of the varicella zoster virus. However, there are no economic evaluation studies on the concurrent introduction of the two vaccines in a population. Besides, the decrease in varicella transmission could result in a change in the age bracket at risk of herpes zoster. However, it is extremely important to monitor and analyze these two diseases, which exert a substantial impact on public health, in order to guarantee that vaccination programs are producing the expected benefits 12 .

Any economic analysis that assumes an increase in zoster incidence after varicella vaccination will present unfavorable results for inclusion of the vaccine. Taking Brisson \& Edmunds 40 as an example, the WAIFW nearly tripled with the inclusion of zoster. In the strategy based on vaccination of children at one year of age, the values ranged from PPP\$46,482 to PPP\$123,443, and in the strategy with vaccination of children at one year of age plus catch-up they varied from PPP $\$ 53,128$ to PPP\$156,662.

The second dose of vaccine against varicella is expected to reduce the number of vaccine failures and thus reduce the number of vaccinated individuals that remain susceptible after one dose of the vaccine 61 . However, two doses of the vaccine nearly double the total cost of vaccination. If this cost increase is not compensated for by a reduction in the cost of vaccine failures, it may negatively impact the vaccination program's cost-effectiveness ${ }^{3}$.

\section{Conclusions}

In most of the studies reviewed, universal childhood vaccination programs against varicella proved to be cost-saving (i.e., generated savings) from society's perspective. According to five studies 42,45,46,48,52 they were cost-saving from the perspectives of both society and the payer. Three of these studies 42,48,52 were done in Germany, where productivity costs are also assessed from the payer's perspective.

The only studies in which childhood vaccination was not considered a cost-effective strategy were those that considered the increase in cases of post-varicella vaccination zoster $26,40,43$. However, the relationship between vaccination against varicella in childhood and zoster incidence in the population with latent varicella zoster infection has still not been completely elucidated, and the results of these modeling studies are considered speculative. It is crucially important to conduct studies on the process of zoster reactivation and 
herpes zoster surveillance following introduction of the varicella vaccine.

In the case of varicella, the indirect costs from absenteeism and loss of associated productivity are more important than the direct costs of treating the disease. Thus, indirect costs should be defined, measured, and assessed better, because the introduction of a universal childhood vaccination program may represent a preventive strategy with major social and economic impact.

Due to the complexity of varicella epidemiology, dynamic models are recommended for analyzing childhood vaccination programs, since they are the only ones capable of modeling the indirect effects of vaccination, which are so important in determining the programs' costeffectiveness.

The programs' cost-effectiveness was heavily related to the price of the vaccine used. The emerging concept of the need for a second dose of vaccine will require better negotiation efforts. It is possible that larger discounts on the vaccine price will be achieved with large purchase volumes or competition between vaccine manufacturers, which may thus lead to a price drop.

\section{Resumo}

O presente trabalho tem por objetivo rever a literatura sobre avaliação econômica de programas de vacinação infantil contra varicela, e discutir como a heterogeneidade em aspectos metodológicos e na estimativa dos parâmetros pode afetar os resultados dos estudos. Após aplicação dos critérios de inclusão, 27 estudos do período de 1980 a 2008 foram analisados com relação às diferenças metodológicas. Observou-se grande heterogeneidade na perspectiva adotada, valoração dos custos indiretos, tipo de modelo empregado, modelagem do efeito no herpes zoster, e na estimativa dos parâmetros de preço e eficácia da vacina. O fator que mais impactou os resultados foi a inclusão dos custos indiretos seguido da perspectiva e preço de vacina adotados. A escolha de um determinado aspecto metodológico ou parâmetro afetou os resultados e conclusões dos estudos. É de fundamental importância que os autores apresentem essas escolhas com transparência para que os usuários das avaliações econômicas compreendam as repercussões dessas escolhas, e em qual direção os resultados das análises foram conduzidos.

Avaliação de Custo-Efetividade; Custos e Análise de Custo; Programas de Imunização; Varicela
Since the vaccine's efficacy also played an important role in the programs' cost-effectiveness, it is recommended to use effectiveness data from post-vaccination studies, since they are more realistic than efficacy data based on clinical trials.

In conclusion, we observed a wide heterogeneity in the perspectives, assessment of indirect costs, type of model, modeling of the effect on herpes zoster, and estimation of the vaccine price and efficacy parameters. The choice of a given methodological aspect or parameter affected the studies' results and conclusions. It is crucial for the authors to present these choices transparently, and that readers and users of economic evaluations understand the repercussions of these choices, i.e., in which direction (for or against) the results were conducted. Since Brazil is currently reviewing its decision on whether or not universal childhood vaccination against varicella should be adopted, we have the chance to benefit from the experience of countries that have already introduced the vaccine, as well as the results of various published economic evaluation studies.

\section{Contributors}

P. C. de Soárez participated in the data analysis and interpretation and writing and critical revision of the article. H. M. D. Novaes critically revised the article. A. M C. Sartori participated in the data analysis and interpretation and critically revised the article. All the authors approved the final version for publication. 
1. Williams I, McIver S, Moore D, Bryan S. The use of economic evaluation in NHS decision-making: a review and empirical investigation. Health Technol Assess 2008; 12:1-175.

2. Thiry N, Beutels P, Van Damme P, Van Doorslaer E. Economic evaluations of varicella vaccination programmes: a review of the literature. Pharmacoeconomics 2003; 21:13-38.

3. Rozenbaum MH, van Hoek AJ, Vegter S, Postma MJ. Cost-effectiveness of varicella vaccination programs: an update of the literature. Expert Rev Vaccines 2008; 7:753-82.

4. Szucs TD. Health economic research on vaccinations and immunisation practices: an introductory primer. Vaccine 2005; 23:2095-103.

5. Johannesson M. The relationship between cost-effectiveness analysis and cost-benefit analysis. Soc Sci Med 1995; 41:483-9.

6. Drummond MF, McGuire A. Economic evaluation in health care: merging theory with practice. $\mathrm{Ox}$ ford: Oxford University Press; 2001.

7. Brisson M, Edmunds WJ. Economic evaluation of vaccination programs: the impact of herd immunity. Med Decis Making 2003; 23:76-82.

8. Beutels P, Van Doorslaer E, Van Damme P, Hall J. Methodological issues and new developments in the economic evaluation of vaccines. Expert Rev Vaccines 2003; 2:649-60.

9. Edmunds WJ, Medley GF, Nokes DJ. Evaluating the cost-effectiveness of vaccination programmes: a dynamic perspective. Stat Med 1999; 18:3263-82.

10. Brisson M, Edmunds WJ, Gay NJ, Law B, De Serres G. Modelling the impact of immunization on the epidemiology of varicella zoster virus. Epidemiol Infect 2000; 125:651-69.

11. Brisson M, Edmunds WJ. Impact of model, methodological, and parameter uncertainty in the economic analysis of vaccination programs. Med Decis Making 2006; 26:434-46.

12. Reynolds MA, Chaves SS, Harpaz R, Lopez AS, Seward JF. The impact of the varicella vaccination program on herpes zoster epidemiology in the United States: a review. J Infect Dis 2008; 197 Suppl 2:S224-7.

13. Weibel RE, Neff BJ, Kuter BJ, Guess HA, Rothenberger CA, Fitzgerald AJ, et al. Live attenuated varicella virus vaccine. Efficacy trial in healthy children. N Engl J Med 1984; 310:1409-15.

14. Kuter BJ, Weibel RE, Guess HA, Matthews H, Morton $\mathrm{DH}$, Neff BJ, et al. Oka/Merck varicella vaccine in healthy children: final report of a 2-year efficacy study and 7-year follow-up studies. Vaccine 1991; 9:643-7.

15. Krause PR, Klinman DM. Efficacy, immunogenicity, safety, and use of live attenuated chickenpox vaccine. J Pediatr 1995; 127:518-25.

16. Arbeter AM, Starr SE, Plotkin SA. Varicella vaccine studies in healthy children and adults. Pediatrics 1986; 78(4 Pt 2):748-56.

17. White CJ, Kuter BJ, Hildebrand CS, Isganitis KL, Matthews $\mathrm{H}$, Miller WJ, et al. Varicella vaccine (VARIVAX) in healthy children and adolescents: results from clinical trials, 1987 to 1989 . Pediatrics 1991; 87:604-10.
18. American Academy of Pediatrics. Committee on Infectious Diseases. Varicella vaccine update. Pediatrics 2000; 105(1 Pt 1):136-41.

19. Bayer O, Heininger U, Heiligensetzer C, von Kries R. Metaanalysis of vaccine effectiveness in varicella outbreaks. Vaccine 2007; 25:6655-60.

20. Marin M, Watson TL, Chaves SS, Civen R, Watson BM, Zhang JX, et al. Varicella among adults: data from an active surveillance project, 1995-2005. J Infect Dis 2008; 197 Suppl 2:S94-S100.

21. Chaves SS, Gargiullo P, Zhang JX, Civen R, Guris D, Mascola L, et al. Loss of vaccine-induced immunity to varicella over time. N Engl J Med 2007; 356:1121-9.

22. Guris D, Jumaan AO, Mascola L, Watson BM, Zhang JX, Chaves SS, et al. Changing varicella epidemiology in active surveillance sites: United States, 1995-2005. J Infect Dis 2008; 197 Suppl 2:S71-5.

23. Marin M, Guris D, Chaves SS, Schmid S, Seward JF. Prevention of varicella: recommendations of the Advisory Committee on Immunization Practices (ACIP). MMWR Recomm Rep 2007; 56(RR-4):1-40.

24. Marin M, Meissner HC, Seward JF. Varicella prevention in the United States: a review of successes and challenges. Pediatrics 2008; 122:744-51.

25. Scuffham PA, Lowin AV, Burgess MA. The cost-effectiveness of varicella vaccine programs for Australia. Vaccine 1999; 18:407-15.

26. Goldman GS. Cost-benefit analysis of universal varicella vaccination in the U.S. taking into account the closely related herpes-zoster epidemiology. Vaccine 2005; 23:3349-55.

27. Perez-Rubio A, Castrodeza-Sanz JJ, Gil-Costa M, Luquero-Alcalde FJ, Eiros-Bouza J, Ortiz-de-Lejarazu R. Impacto social y económico de la vacunación frente a la varicela a los 15 meses de edad en Castilla y León en 2004. Rev Esp Salud Pública 2008; 82:101-9.

28. Zhou F, Ortega-Sanchez IR, Guris D, Shefer A, Lieu $\mathrm{T}$, Seward JF. An economic analysis of the universal varicella vaccination program in the United States. J Infect Dis 2008; 197 Suppl 2:S156-64.

29. Bonanni P, Boccalini S, Bechini A, Banz K. Economic evaluation of varicella vaccination in Italian children and adolescents according to different intervention strategies: the burden of uncomplicated hospitalised cases. Vaccine 2008; 26:5619-26.

30. Valentim J, Sartori AM, de Soárez PC, Amaku M, Azevedo RS, Novaes HM. Cost-effectiveness analysis of universal childhood vaccination against varicella in Brazil. Vaccine 2008; 26:6281-91.

31. World Bank. Resultados mundiales para el PCI 2005: tabla resumen. Boletín del ICP 2008; 5(1). http:// www-wds.worldbank.org/external/default/WDS ContentServer/WDSP/IB/2008/08/21/000333038 20080821011936/Rendered/PDF/438140NEWS0S PAlletter0511101PUBLIC1.pdf (accessed on 20/ Nov/2008).

32. Preblud SR, Orenstein WA, Koplan JP, Bart KJ, Hinman AR. A benefit-cost analysis of a childhood varicella vaccination programme. Postgrad Med J 1985; 61 Suppl 4:17-22. 
33. Huse DM, Meissner HC, Lacey MJ, Oster G. Childhood vaccination against chickenpox: an analysis of benefits and costs. J Pediatr 1994; 124:869-74.

34. Lieu TA, Cochi SL, Black SB, Halloran ME, Shinefield HR, Holmes SJ, et al. Cost-effectiveness of a routine varicella vaccination program for US children. JAMA 1994; 271:375-81.

35. Beutels P, Clara R, Tormans G, Van Doorslaer E, Van Damme P. Costs and benefits of routine varicella vaccination in German children. J Infect Dis 1996; 174 Suppl 3:S335-41.

36. Coudeville L, Paree F, Lebrun T, Sailly J. The value of varicella vaccination in healthy children: costbenefit analysis of the situation in France. Vaccine 1999; 17:142-51.

37. Scuffham P, Devlin N, Eberhart-Phillips J, WilsonSalt R. The cost-effectiveness of introducing a varicella vaccine to the New Zealand immunisation schedule. Soc Sci Med 1999; 49:763-79.

38. Diez-Domingo J, Ridao M, Latour J, Ballester A, Morant A. A cost-benefit analysis of routine varicella vaccination in Spain. Vaccine 1999; 17:1306-11.

39. Hudeckova H, Straka S, Rusnakova S. Epidemiological features and economic evaluation of a potential chickenpox vaccination strategy in Slovak Republic. Cent Eur J Public Health 2000; 8:227-8.

40. Brisson M, Edmunds WJ. The cost-effectiveness of varicella vaccination in Canada. Vaccine 2002; 20:1113-25.

41. Getsios D, Caro JJ, Caro G, De Wals P, Law BJ, Robert $\mathrm{Y}$, et al. Instituting a routine varicella vaccination program in Canada: an economic evaluation. Pediatr Infect Dis J 2002; 21:542-7.

42. Banz K, Wagenpfeil S, Neiss A, Goertz A, Staginnus $\mathrm{U}$, Vollmar J, et al. The cost-effectiveness of routine childhood varicella vaccination in Germany. Vaccine 2003; 21:1256-67.

43. Brisson M, Edmunds WJ. Varicella vaccination in England and Wales: cost-utility analysis. Arch Dis Child 2003; 88:862-9.

44. Hsu HC, Lin RS, Tung TH, Chen TH. Cost-benefit analysis of routine childhood vaccination against chickenpox in Taiwan: decision from different perspectives. Vaccine 2003; 21:3982-7.

45. Coudeville L, Brunot A, Giaquinto C, Lucioni C, Dervaux B. Varicella vaccination in Italy: an economic evaluation of different scenarios. Pharmacoeconomics 2004; 22:839-55.

46. Ginsberg GM, Somekh E. Cost containment analysis of childhood vaccination against varicella in Israel. J Infect 2004; 48:119-33.

47. Jean-Jasmin LM, Lynette SP, Stefan M, Kai CS, Chew FT, Wah LB. Economic burden of varicella in Singapore: a cost benefit estimate of implementation of a routine varicella vaccination. Southeast Asian J Trop Med Public Health 2004; 35:693-6.
48. Coudeville L, Brunot A, Szucs TD, Dervaux B. The economic value of childhood varicella vaccination in France and Germany. Value Health 2005; 8: 209-22.

49. Gialloreti LE, Divizia M, Pica F, Volpi A. Analysis of the cost-effectiveness of varicella vaccine programmes based on an observational survey in the Latium region of Italy. Herpes 2005; 12:33-7.

50. Tseng HF, Tan HF, Chang CK. Varicella epidemiology and cost-effectiveness analysis of universal varicella vaccination program in Taiwan. Southeast Asian J Trop Med Public Health 2005; 36: 1450-8.

51. Lenne X, Diez-Domingo J, Gil A, Ridao M, Lluch JA, Dervaux B. Economic evaluation of varicella vaccination in Spain: results from a dynamic model. Vaccine 2006; 24:6980-9.

52. Hammerschmidt T, Bisanz H, Wutzler P. Universal mass vaccination against varicella in Germany using an MMRV combination vaccine with a twodose schedule: an economic analysis. Vaccine 2007; 25:7307-12.

53. Saddier P, Floret D, Guess HA, Durr F, Peyrieux JC, Weber DJ, et al. Cost of varicella in France: a study in day care centers. J Infect Dis 1998; 178 Suppl 1: S58-63.

54. Halloran ME, Cochi SL, Lieu TA, Wharton M, Fehrs L. Theoretical epidemiologic and morbidity effects of routine varicella immunization of preschool children in the United States. Am J Epidemiol 1994; 140:81-104.

55. Hambleton S, Gershon AA. Preventing varicellazoster disease. Clin Microbiol Rev 2005; 18:70-80.

56. Seward JF, Marin M, Vazquez M. Varicella vaccine effectiveness in the US vaccination program: a review. J Infect Dis 2008; 197 Suppl 2:S82-9.

57. Kuter B, Matthews H, Shinefield H, Black S, Dennehy P, Watson B, et al. Ten year follow-up of healthy children who received one or two injections of varicella vaccine. Pediatr Infect Dis J 2004; 23:132-7.

58. Brisson M, Edmunds WJ, Gay NJ, Law B, De Serres G. Analysis of varicella vaccine breakthrough rates: implications for the effectiveness of immunisation programmes. Vaccine 2000; 18:2775-8.

59. Brouwer WB, Koopmanschap MA, Rutten FF. Productivity costs measurement through quality of life? A response to the recommendation of the Washington Panel. Health Econ 1997; 6:253-9.

60. Brisson M, Edmunds WJ, Gay NJ. Varicella vaccination: impact of vaccine efficacy on the epidemiology of VZV. J Med Virol 2003; 70 Suppl 1:S31-7.

61. Sengupta N, Booy R, Schmitt HJ, Peltola H, VanDamme P, Schumacher RF, et al. Varicella vaccination in Europe: are we ready for a universal childhood programme? Eur J Pediatr 2008; 167:47-55.

Submitted on 08/May/2009

Final version resubmitted on 17/Jul/2009

Approved on 19/Aug/2009 